\title{
Description of Latvian Metal Production and Processing Enterprises`Air Emissions
}

\author{
Jelena Pubule, Riga Technical University, Institute of Energy Systems and Environment, Dace Zahare, Riga \\ Technical University, Institute of Energy Systems and Environment, Dagnija Blumberga, Riga Technical University, \\ Institute of Energy Systems and Environment
}

\begin{abstract}
The metal production and processing sector in Latvia has acquired a stable position in the national economy. Smelting of ferrous and nonferrous metals, production of metalware, galvanisation, etc. are developed in Latvia. The metal production and processing sector has an impact on air quality due to polluting substances which are released in the air from metal treatment processes. Therefore it is necessary to determine the total volume of emissions produced by the metal production and processing sector in Latvia. This article deals with the air polluting emissions of the Latvian metal production and processing industry, and sets the optimum sector emission volumes using the emissions benchmark methodology.
\end{abstract}

Keywords - Emissions to air, production and processing of metals, Benchmark methodology, cleaner production, energy efficiency.

\section{I.INTRODUCTION}

Latvia is a small country with limited resources. The development of the national economy is unthinkable without an increase in the production sector. In turn, the development of the production sector is connected with the intensification of production capacity and the resulting consequences - an increase in the air emissions. Applying the principles of cleaner production can significantly reduce emissions. The metal production and processing sector in Latvia has acquired a stable position in the national economy. Smelting of ferrous and nonferrous metals, production of metalware, galvanisation, etc. are developed in Latvia. Metal production and treatment processes have an impact on the air quality as during the production process polluting substances are released into the air. Thus it is necessary to establish the total emissions volume of the Latvian metal production and processing sector. This article deals with the air polluting emissions of the Latvian metal production and processing industry, and sets the optimum sector emission volumes using the emissions benchmark methodology.

\section{II.METAL PRODUCTION AND PROCESSING IN LATVIA}

The protection of human health and ecosystems is gaining importance in corporate decision-making in terms of industrial development [1]. Pursuant to the current regulatory framework of Latvia, before commencement of entrepreneurial activities related to metal production and processing, a permit for carrying out the specific polluting activity shall be obtained. The article examines and analyses enterprises engaged in the polluting activity compliant to Category A or B [2, 3], since the emissions of such enterprises are considered to be the most important ones. Over 50 enterprises operate in the metal production and processing sector, most of them are engaged in production of metalware, for example, furniture accessories, traffic signs, metal sheet items. Metal items are predominantly produced from ferrous metals. It is important to mention that enterprises differ as to their production volume, capacity, and energy efficiency. The enterprise-generated emissions depend on both the production volume, and the applied processing method. At the same time, it shall be noted that the emission volumes are greatly dependent on the enterprise production standards.

There are metal smelting enterprises in Latvia which are engaged in the smelting of both ferrous and nonferrous metals. In fact this is metal recycling - not primary production. Recycling constitutes an important portion of the raw material supplies of a number of metals. Copper, aluminium, lead, zinc, precious metals and refractory metals, among others, can be recovered from their products or residues and can be returned to the production process without any loss in quality through recycling. Overall, secondary raw materials account for a high proportion of production, thus reducing the consumption of raw materials and energy [3]. The biggest enterprises are engaged in the recycling of nonferrous metals. They recycle the scrap metal gathered not only in Latvia, but also in other Baltic countries. Due to that which is described above, these particular enterprises should also be regarded as waste disposal enterprises, since, pursuant to the regulations, waste is any object or substance which the possessor thereof disposes of, or intends to or is forced to dispose of, and which conforms to the categories specified in the waste classification [4].

Enterprises engaged in galvanisation deserve special attention, as the galvanisation residue is a kind of waste requiring special treatment. To date Latvia has not settled the issue of reducing historical pollution related to the galvanisation industry. Territories where equipment for galvanisation of surfaces was located are still used as storage areas for galvanisation waste. Companies which perform galvanisation works in Latvia vary: from modern enterprises to companies where optimisation is an essential step as a preventive measure to resolve environmental issues.

Production of metalware results in air emissions. The article provides for emission analysis of volatile organic compounds (VOC), nitrogen dioxide $\left(\mathrm{NO}_{2}\right)$ and carbon monoxide $(\mathrm{CO})$. The study does not cover dust and ferrous oxide emissions. 


\section{III.DESCRIPTION OF POLLUTING SUBSTANCES}

Volatile organic compounds (VOC) refer to the group of chemical compounds containing carbon. They may be manmade or natural. VOCs react with nitrogen oxide which is known as a significant air polluting agent and creates chemical smog in the sunlight [5].

Some VOCs contain formaldehydes, benzene and metylbenzene. These substances are often used as solvents for paints, varnishes and cleaning substances; mainly emitted from production equipment where organic solvents are used.

VOCs emission sources are households, transport, industrial production processes, use of solvents and specific chemicals (paints, varnishes, polymer coating materials, etc.), as well as the burning of waste. VOC emissions in Latvia in the period from 1990 to 2005 have decreased by approximately $34 \%$. The largest VOC amounts were emitted by households mostly due to the increasing consumption of wood fuel [6]. The most VOC emissions in the household sector were generated in $2005-67.7 \%$. The emissions of volatile organic compounds in 2009 are displayed in Fig. 1.

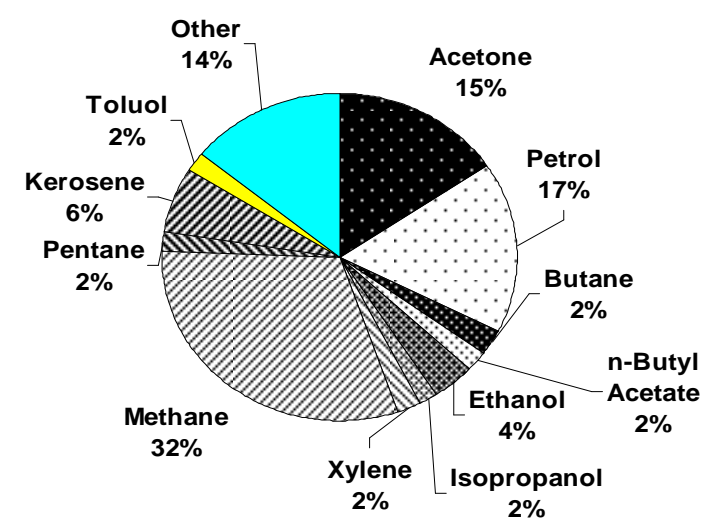

Fig. 1. The emissions of volatile organic compounds in 2009.

Most VOC emissions are due to methane, petrol, acetone, isopropanol, kerosene. In 2009 VOC emissions in Latvia were 3202.28 tons.

The main source of nitrogen oxide emissions is transport, especially motor transport. $\mathrm{NO}_{2}$ emissions from use of fuel for non-energetic needs, industrial production processes, burning of last year's grass, field husbandry, forestry, and burning of waste are insignificant. In 2005 the transport sector was responsible for already $52.3 \%$ of the total $\mathrm{NO}_{2}$ emissions. The relative impact of transport on $\mathrm{NO}_{2}$ emissions has increased, in turn the impact of energy production sector has decreased nearly by one half; the reason thereof is a substantial increase in the number of transport vehicles and the growing use of natural gas for energy production. Since the year 2000, with an increase in energy production, the nitrogen oxide emissions from combustion appliances is gradually rising [7].

Carbon monoxide is a toxic gas which results from incomplete combustion of all carbon containing products. It shall be mentioned that the amounts of carbon monoxide emissions in the metal production and processing sector are substantial.

The year by year changes in emissions of $\mathrm{SO}_{2}, \mathrm{NO}_{2}, \mathrm{CO}$ and VOC are displayed in Fig. 2. The total amount of polluting substances in the last 15 years has significantly reduced. However, in view of the trend in recent years, it shall be mentioned that the amount of emissions is no longer decreasing. It means that, in case of an increase in production capacity, the amount of emissions in the country will go up. The increase might be less if the production sector would develop and apply the benchmark methodology for emissions control. This would allow enterprises to evaluate the total sector emissions, average indicators and the benchmark value.

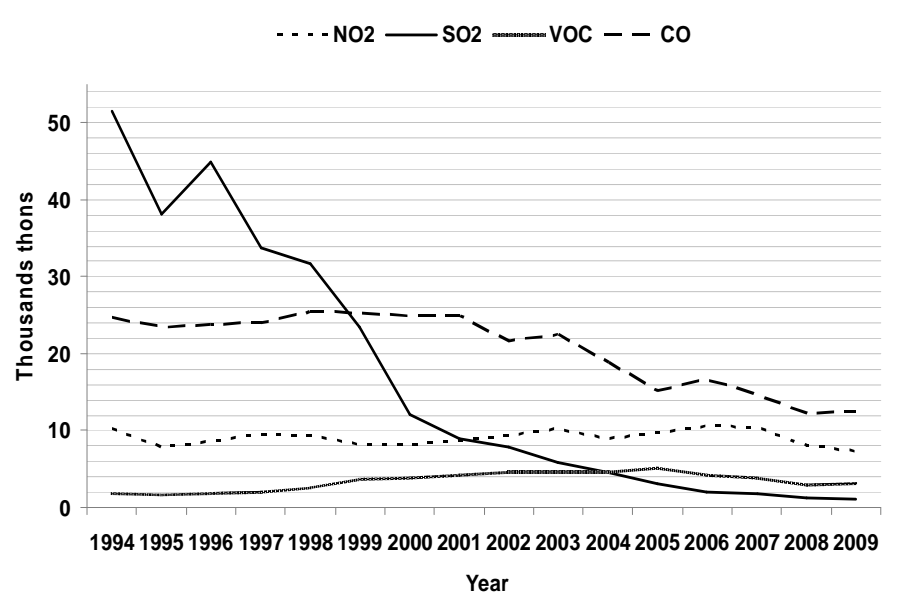

Fig. 2. Changes in emissions by years.

\section{IV.RESEARCH METHODOLOGY}

In this article, the benchmark methodology is based on the identification of criteria used in the benchmark methodology and consists of the following steps:

1. Data collection on the metal production and processing sector in Latvia;

2. Identification and verification of quantitative and qualitative indicators;

3. Development of criteria and the application of he benchmark methodology.

Within the framework of the study, permits issued by the regional environmental boards of the State Environmental Service of Latvia to enterprises engaged in metal production and processing were examined. Such permits establish the maximum permissible emission amounts generated at full enterprise capacity. At present a number of enterprises do not work at full capacity, therefore the actual emissions are less, and the yearly statistical report "2-Air" indicates proportionally lower emissions compared to those set in permits. When submitting reports, enterprises do not make direct emissions calculations, instead they establish the amount of emissions using the calculation methodology indicated in the permit. Thus, one can say that in a more favourable economic situation, enterprises would produce the emissions indicated in the respective permits. 
Pursuant to the current Latvian legislation, the polluting activity shall not be initiated if environmental quality standard limit values for a specific type of pollution in a specific territory have been exceeded or may be exceeded and if the emissions caused by the relevant activity may increase the total quantity of the relevant pollution in this territory. In such cases permits for carrying out polluting activity shall not be issued [2]. At the same time, when establishing benchmark values of environmental quality standards for a certain kind of pollution in a set territory, the amounts as per report of polluting activity are used instead of those amounts established by the permits for the polluting activity. This may result in a situation whereby a polluting activity is permitted in a territory where the environmental quality standards for a certain kind of pollution are exceeded, provided that all enterprises having an impact on such a territory operate at full capacity.

\section{CHOICE OF INDICATORS}

Metal production and treatment processes vary. They may be divided into groups according to the type and specific features of production, and the qualities of the products. When developing a benchmark for the metal production and processing sector, enterprises were divided into three groups: metalware production enterprises, metal re-smelting enterprises, and galvanisation enterprises.

In the metal production sector, the types and amounts of emissions and the capacity and energy consumption of 24 enterprises were analysed.

In the metal re-smelting group 11 enterprises were analysed; and 6 enterprises in the galvanisation group. The study resulted in the development of emissions description criteria.

For bigger enterprises, emissions would be higher and a simple comparison would not enable to establish the company efficiency criteria. To make an objective evaluation of the volume of emissions, it was decided to use the specific emission amounts as criteria for the benchmark methodology.

\section{A. Production of Metalware}

Through the analysis of the metalware production group it was established that it comprises of companies with the capacity from 0.4 to $9.32 \mathrm{MW}$. The volume of production is between 300 and 7105 tons of treated metal per year.

In the metalware production group the following specific emission amounts shall be used as criteria: $\mathrm{NO}_{2}$ emissions per production unit; $\mathrm{CO}$ emissions per production unit; VOC emissions per production unit.

Use of such criteria allows for establishing the current specific emissions of the Latvian metalware production sector, and set a benchmark to be achieved in the coming years. The specific capacity of production enterprises was examined within the framework of the study; it was established that at the increase in capacity the amount of the specific capacity is also increasing (see Fig. 3).

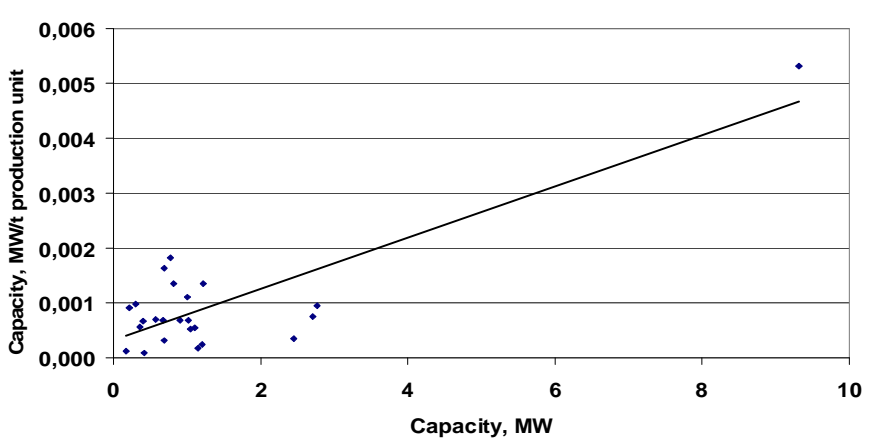

Fig. 3. Specific correlation between capacity and production unit. Production of Metalware.

In accordance with the Reference Document on Best Available Techniques in the Ferrous Metals Processing Industry, the main environmental protection issues connected with hot rolling are emissions in the air, especially $\mathrm{NO}_{2}$ un $\mathrm{SOx}$; furnace energy consumption; dust emissions during the product treatment process, hot rolling or mechanical treatment of surface, as well as the emissions of oil and solid particles and oil-containing waste [8].

It is proposed to use the following specific emissions as criteria in the metal production and processing sector:

1. $\mathrm{NO}_{2}$ emissions per production unit (see Fig. 4).

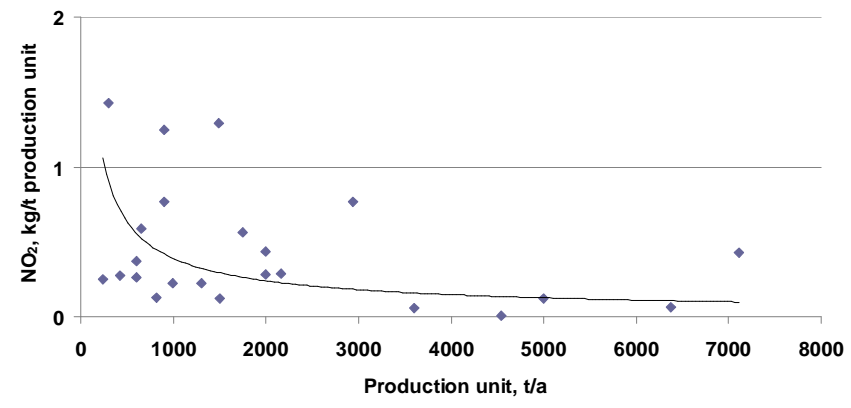

Fig. 4. Specific correlation between $\mathrm{NO}_{2}$ emissions and production unit.

Analysing the obtained data it was concluded that in some enterprises it is possible to reduce $\mathrm{NO}_{2}$ specific emissions by installing air treatment equipment.

2. $\mathrm{CO}$ emissions per production unit (see Figure 5.)

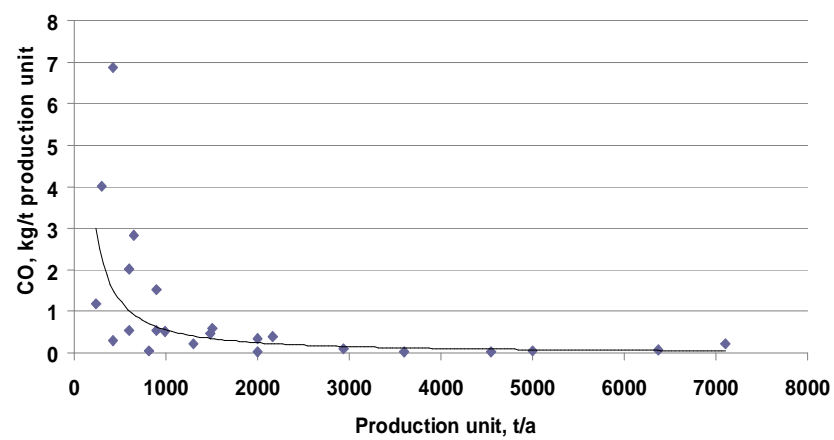

Fig. 5. Specific correlation between $\mathrm{CO}$ emissions and production unit. 
The above mentioned correlation indicates that it is possible to reduce the specific carbon oxide emissions of production enterprises. This can be achieved by providing for complete fuel combustion and introducing cleaner production measures.

3. VOC emissions per production unit.

VOC emissions are a result of metalware production - some of production stages involve painting of items or treatment thereof with special compounds.

The specific VOC emissions per production unit reflect the current situation and enable to establish that the specific VOC emissions decrease at the increase of the amount of manufactured production. (see Fig. 6).

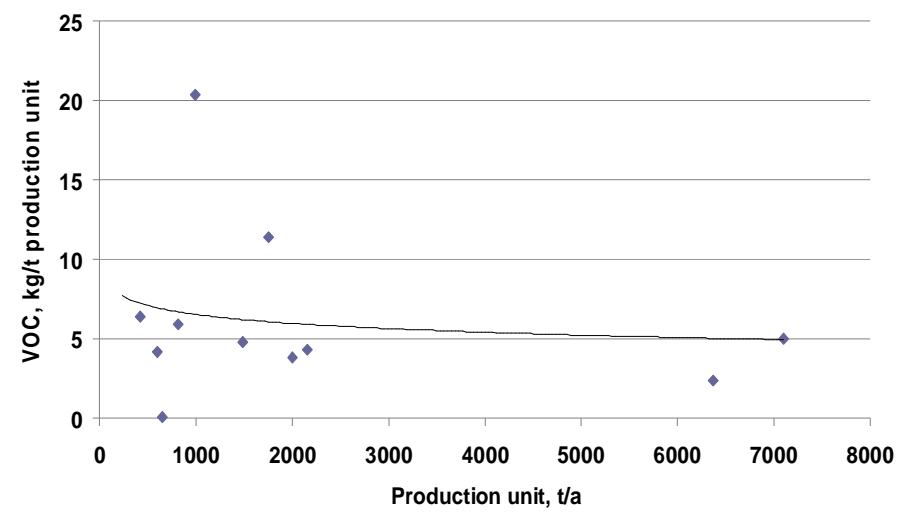

Fig. 6. Specific correlation between VOC emissions and production unit.

\section{B. Metal smelting}

Metal smelting comprises smelting of various metals in special smelting furnaces.

In Latvia re-smelting of nonferrous metals dominates; however, also re-smelting of ferrous metals is performed. By analysing the metal re-smelting group, it was established that the group includes enterprises with the capacity from 0.29 to $22.6 \mathrm{MW}$. The amount of treated metal varies between 3600 and 150000 tons of smelting per year.

At metal re-smelting enterprises the capacity of smelting furnaces is of great importance. The amount of smelted metal depends on the capacity of these furnaces. Therefore in the metal re-smelting sector, the following specific emissions are proposed as criteria of evaluation: $\mathrm{NO}_{2}$ emissions per production unit and $\mathrm{CO}$ emissions per production unit.

Using these criteria enables to establish the Latvian metal re-smelting sector specific emissions and set a benchmark using the emissions suggested by the best technical methods.

The study deals with the specific emissions of metal smelting enterprises and finds that, with an increase in capacity, the amount of specific capacity also increases, like in the metalware production group (see Fig. 7).

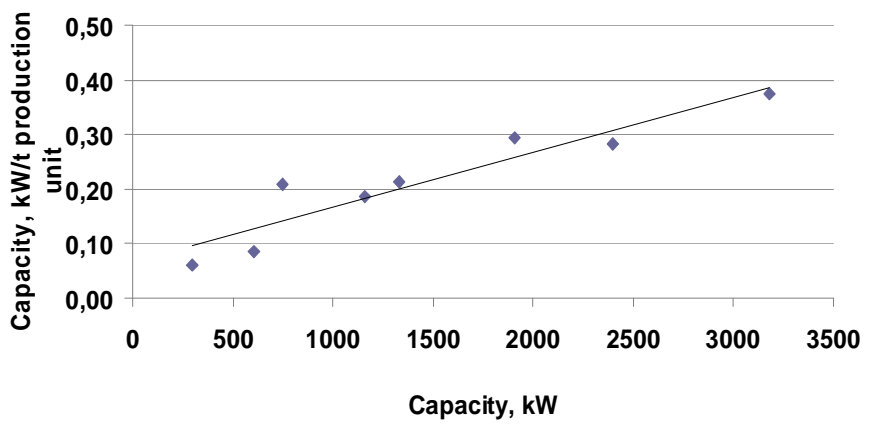

Fig. 7. Specific correlation between capacity and production unit. Metal smelting.

The data provided has confirmed that the significance of fugitive emissions in many processes is very high and that fugitive emissions can be much greater than those that are captured and abated. In these cases it is possible to reduce environmental impact by following the hierarchy of gas collection techniques from material storage and handling, reactors or furnaces and from material transfer points. Potential fugitive emissions must be considered at all stages of the process of design and development. The hierarchy of gas collection from all of the process stages is:

1. Process optimisation and minimisation of emissions;

2. Sealed reactors and furnaces;

3. Targeted fume collection.

Roofline collection of fume has a high energy consumption and should be a last resort [4].

It is proposed to use the following specific emissions as criteria in the metal re-smelting sector:

1. $\mathrm{NO}_{2}$ emissions per capacity (see Fig. 8).

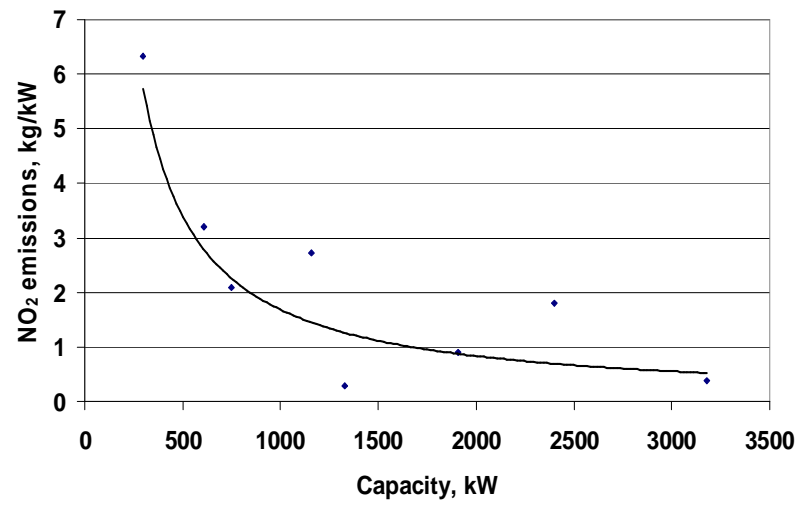

Fig. 8. Specific correlation between $\mathrm{NO}_{2}$ emissions and capacity.

Analysing the above mentioned chart one may conclude that it is possible to reduce $\mathrm{NO}_{2}$ emissions in the metal re-smelting sector. With an increase in capacity the specific emissions are decreasing. In view of this one may conclude that smelting of metal at enterprises with a higher production capacity is more environmentally friendly.

Oxides of nitrogen are relatively insignificant but may be absorbed in the sulphuric acid produced from a primary 
process; the use of oxygen enrichment can sometimes reduce the formation of nitrogen oxides by the thermal route. This depends on the point where oxygen is added, sometimes a higher concentration of nitrogen oxides is produced due to the increase in temperature, however the gas volume and total quantity is lower [4].

2. CO emissions per capacity (see Fig. 9).

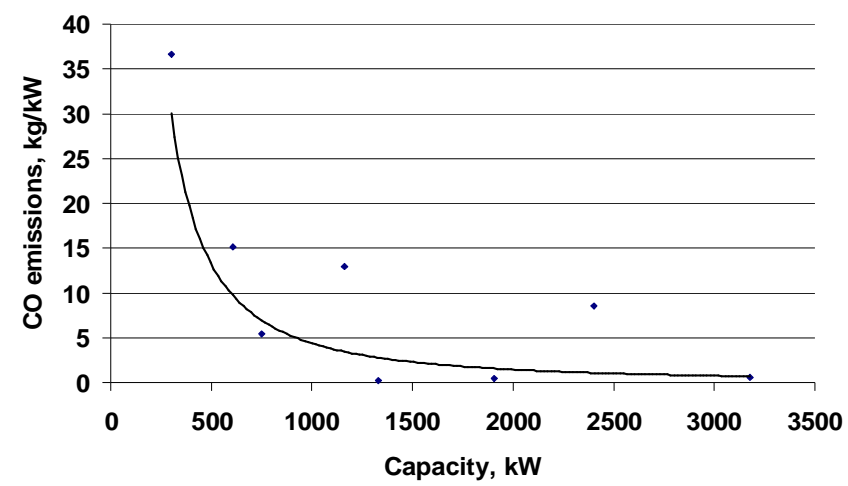

Fig. 9. Specific correlation between CO emissions and capacity.

Like with $\mathrm{NO} 2$ emissions, also $\mathrm{CO}$ specific emissions are decreasing with the increase in capacity which allows for optimisation in the metal re-smelting sector by merging several enterprises into one higher capacity plant.

It is possible to predict ground level concentrations of $\mathrm{CO}$ and this may be used to determine the effect of $\mathrm{CO}$ on local air quality so that further abatement needs can be assessed locally [4].

\section{Metal galvanisation}

The analysis of companies performing metal galvanisation suggested that this group includes companies of a capacity varying from 0.57 to $31.47 \mathrm{MW}$. The volume of the products processed range from 135 to 30750 tonnes per year. A suggestion to use the measure of specific emission per unit of capacity has been made also in the metal galvanisation field. In the metal galvanisation sector, the suggested criteria for benchmarking are the following:

1. $\mathrm{NO}_{2}$ emissions per capacity (see Fig. 10).

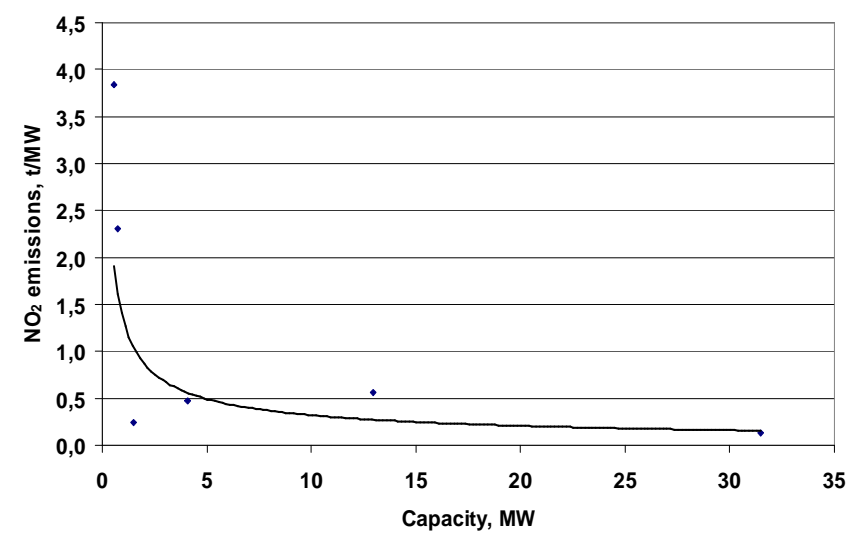

Fig. 10. Specific correlation between $\mathrm{NO}_{2}$ emissions and capacity.
The NO2 emissions are significant air pollutants in the metal galvanisation industry. The galvanisation sector should be paid special attention to, since it has great impact on the environment. As the number of companies offering galvanisation grows, the impact also becomes more substantial.

2. CO emissions per capacity (see Fig. 11).

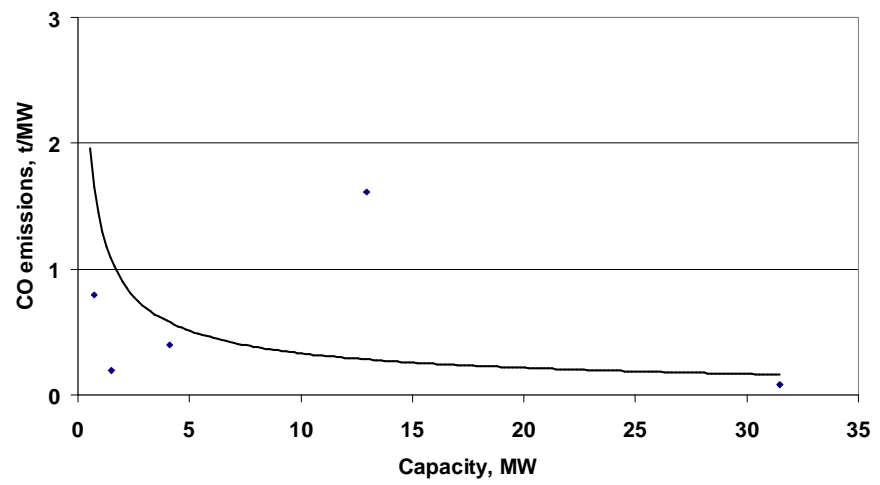

Fig. 11. Specific correlation between $\mathrm{CO}$ emissions and capacity.

The galvanisation process is energy-intensive. Though, it should be mentioned that the permits for the performance of polluting activities issued to the metal galvanisation companies do not indicate the energy consumption. Therefore, it is impossible to evaluate the amount of consumed electrical energy.

The recording of energy consumption is a major step for improving the environmental protection system in Latvia. Therefore, further research on energy consumption in various areas of the national economy is needed, including the production of metalware.

\section{RESUlt ANALysis}

Based on the results of the research and the Best Available Techniques in the Non Ferrous Metals Industries, and Best Available Techniques in the Ferrous Metals Processing Industry, benchmarks for comparing the metal production and processing companies were set.

\section{A Emission Benchmarks for Metalware Manufacturers}

Benchmarks were set for the specific emissions of $\mathrm{NO}_{2}$, $\mathrm{CO}$, and VOC. In the first approximation, the benchmark was $20 \%$ above the average value of specific emissions. As this is the first time when benchmarks are used for metalware manufacturing plants (only the critical values outlined in the regulatory framework are used), such benchmark can be regarded as an optimal one. The optimal value of the chosen benchmarks was examined using the amounts of emissions mentioned in the best available technical methods.

1. $\mathrm{NO}_{2}$ emissions benchmark (see Fig. 12). 


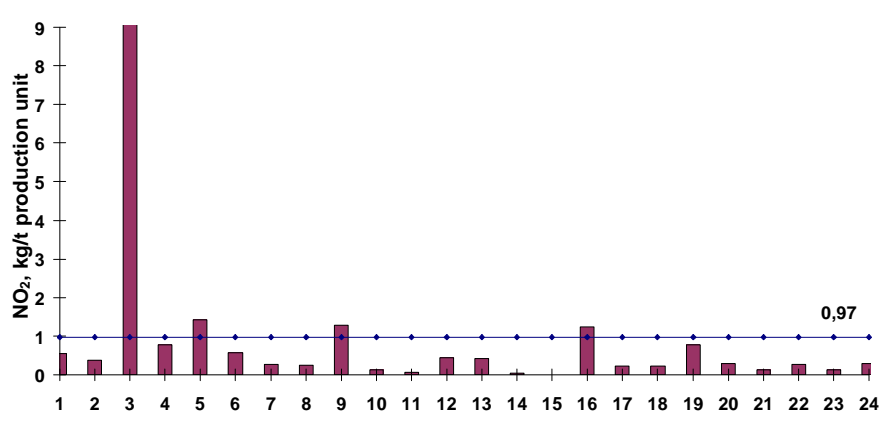

Fig. 12. $\mathrm{NO}_{2}$ emissions benchmark.

According to the Best Available Techniques in the Ferrous Metals Processing Industry, the emissions of $\mathrm{NO}_{2}$ in the EU member states range from 10 to $900 \mathrm{~g} / \mathrm{t}$. For metalware manufacturers, a benchmark of $0.97 \mathrm{~kg}$ of $\mathrm{NO}_{2}$ per ton of production was offered. As the Best Available Techniques (BAT) is binding upon major companies having permits of category A for the performance of polluting activities, the volume of specific emissions slightly exceeding the values of emissions mentioned in the BAT should be regarded as optimal.

If such a benchmark is used, four companies (17\%) will be forced to cut their emissions, e.g. by installing air treatment systems. By applying such a benchmark, the amount $\mathrm{NO}_{2}$ emissions in the air would reduce by $4.5 \%$. Emissions of $\mathrm{NO}_{2}$ resulting from the metalware manufacturing will be cut from $19.3 \mathrm{t} / \mathrm{a}$ to $18.5 \mathrm{t} / \mathrm{a}$.

2. CO emissions benchmark.

Metalware manufacturers are proposed to use $0.87 \mathrm{~kg} \mathrm{CO}$ per production tonne as a benchmark. (see Fig. 13).

If such a benchmark is used, the air would receive $90 \%$ less $\mathrm{CO}$. The $\mathrm{CO}$ emissions from metal products manufacturing will be cut from 775.79 t/a to 84.051 t/a. This reduction can be explained by the fact that the specific emissions of one enterprise account for $64 \%$ of the total emissions (this company is not represented in Figure 13).

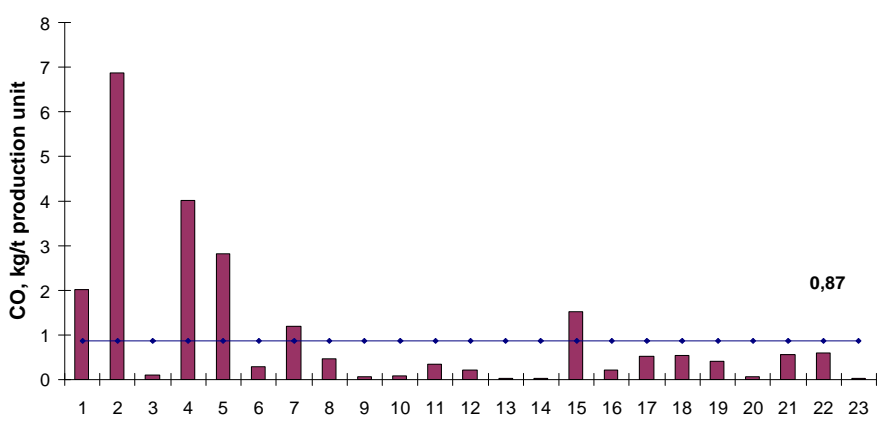

Fig. 13. CO emissions benchmark.

3. VOC emissions benchmark

A benchmark of $7.44 \mathrm{~kg}$ VOC per production tonne is suggested for metalware manufacturers. (see Fig. 14).

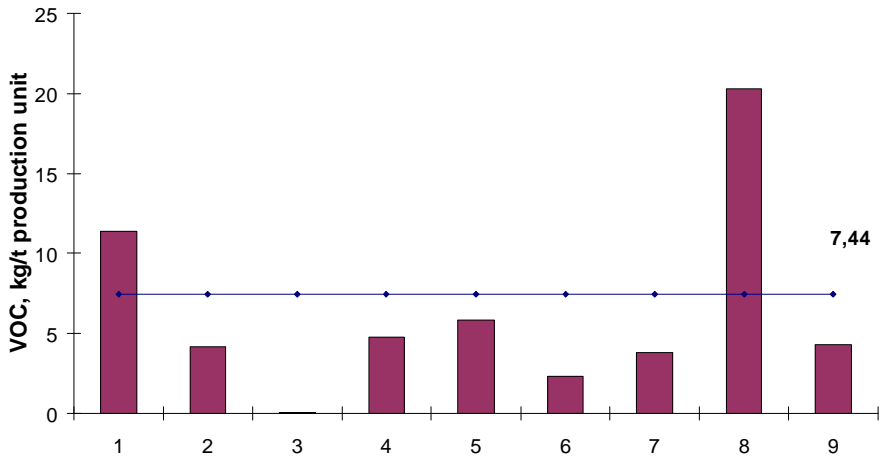

Fig. 14. VOC emissions benchmark.

If such benchmark is used, the air will receive $16 \%$ less VOC emissions. The VOC emissions from metalware manufacturing will be reduced from 121.9 t/a to 102.3 t/a.

\section{B. Emission Benchmarks for Metal Smelting Enterprises}

Benchmarks for the specific emissions of $\mathrm{NO}_{2}$ and $\mathrm{CO}$ were outlined. In the first approximation, the benchmark was set at the following level: $20 \%$ above the average value of the specific emissions. The optimal value of the chosen benchmark was examined, using the amounts of emissions mentioned in the best available technical methods.

1. $\mathrm{NO}_{2}$ emissions benchmark.

Metal re-smelting enterprises are suggested to use $2.66 \mathrm{~kg}$ $\mathrm{NO}_{2}$ per unit of capacity (kW) as a benchmark (see Fig. 15). The value of the benchmark was compared to the emissions amount for different metal smelting companies in different EU member states, as mentioned in the BAT. It was found that the chosen benchmark conforms to the critical value set in the BAT. According to the data presented in the BAT, the critical values for $\mathrm{NO} 2$ emissions range from 80 to $360 \mathrm{~g} / \mathrm{t}$, or from 0.55 to $2.66 \mathrm{~kg} / \mathrm{kW}$.

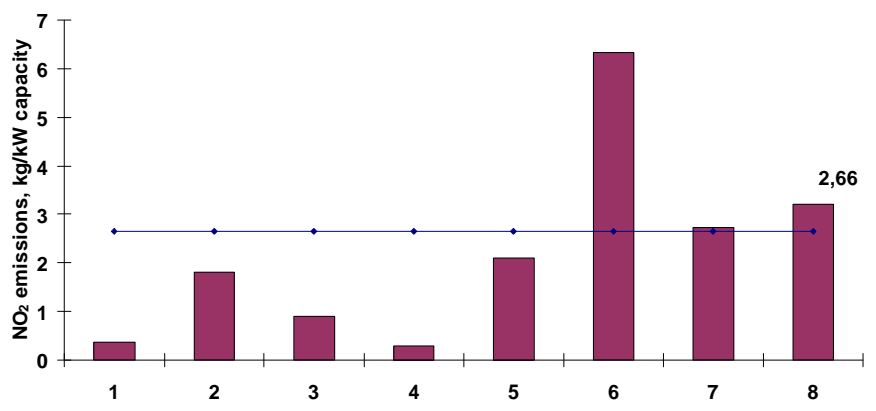

Fig. 15. $\mathrm{NO}_{2}$ emissions benchmark.

If such benchmark is used, three companies (38\%) will have to cut their emissions, e.g. by installing air treatment systems. Such a benchmark would ensure that the emissions of $\mathrm{NO}_{2}$ in the air would reduce by $16.5 \%$. The amount of $\mathrm{NO}_{2}$ emissions from metal smelting would be cut from 62.89 t/a to 52.52 t/a. 2. $\mathrm{CO}$ emissions benchmark (see Fig. 16). 


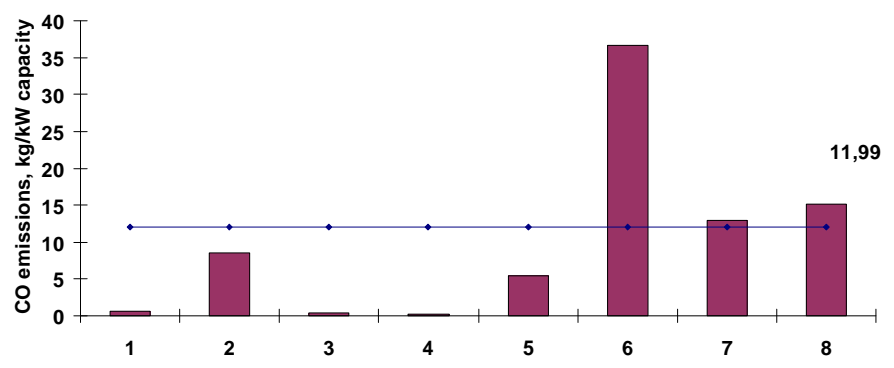

Fig. 16. CO emissions benchmark.

Metal re-smelting enterprises are suggested to use $11.99 \mathrm{~kg}$ $\mathrm{CO}$ per unit of capacity $(\mathrm{kW})$ as a benchmark. If such a benchmark is used, three companies (38\%) will have to cut their emissions, e.g. by installing air treatment systems. Such a benchmark would ensure that the emissions of $\mathrm{CO}$ in the air basin would reduce by $9 \%$. The amount of $\mathrm{CO}$ emissions from metal smelting would be cut from 16.21 t/a to $14.71 \mathrm{t} / \mathrm{a}$.

\section{Emission Benchmarks for Metal Galvanisation Enterprises}

Benchmarks for the specific emissions of NO2 and CO were outlined. In the first approximation, the benchmark was set at the following level: $20 \%$ above the average value of the specific emissions.

Taking into account that the chosen benchmarks for metalware manufacturing companies and metal smelting companies were regarded as optimal, after being compared to the level of emissions mentioned in the BAT, also the metal galvanisation companies are offered to use the benchmarks set according to the same principles.

1. $\mathrm{NO}_{2}$ emissions benchmark.

Two out of six companies performing metal galvanisation have to reorganise their activity in order to meet the benchmark. The offered benchmark for metal galvanisation companies is $1.51 \mathrm{t}$ of $\mathrm{NO}_{2}$ per unit of capacity (MW) (see Fig. 17).

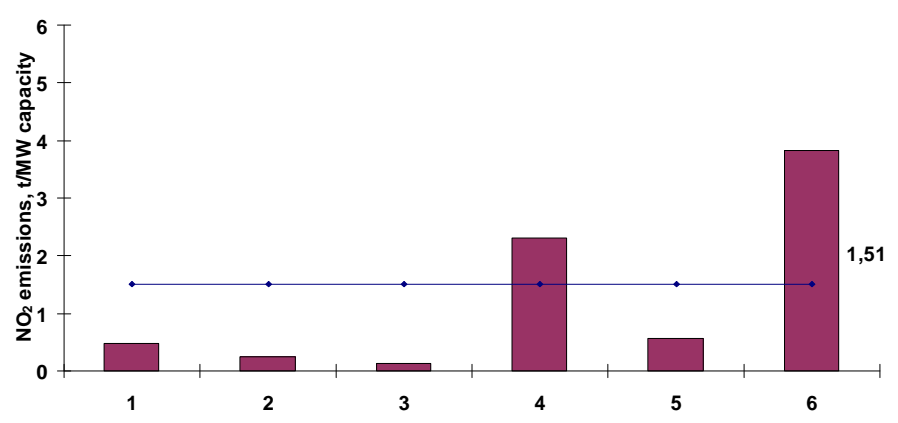

Fig.17. $\mathrm{NO}_{2}$ emissions benchmark.

If such benchmark is used, the air basin will receive up to $10.3 \%$ less $\mathrm{NO}_{2}$. The $\mathrm{NO}_{2}$ emissions from the metalware manufacturing will reduce from 17.74 t/a to $15.91 \mathrm{t} / \mathrm{a}$.

2. CO emissions benchmark (see Fig. 18).

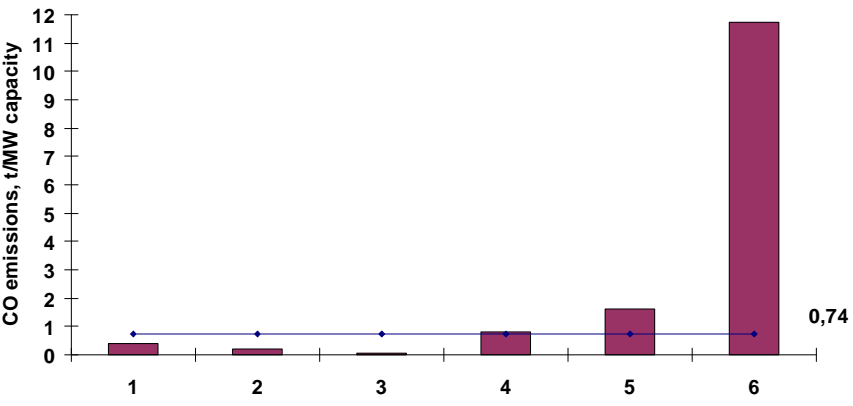

Fig.18. CO emissions benchmark.

Two out of six companies performing metal galvanisation have to reorganise their activity in order to meet the benchmark. The offered benchmark for metal galvanisation companies is $0.74 \mathrm{t}$ of $\mathrm{CO}$ per unit of capacity (MW). If such a benchmark is used, the air basin will receive up to $54 \%$ less $\mathrm{CO}$. The $\mathrm{CO}$ emissions from the metalware manufacturing will reduce from $32.63 \mathrm{t} / \mathrm{a}$ to $15 \mathrm{t} / \mathrm{a}$.

\section{DISSCUSSION}

The results acquired and empiric benchmark equations can be used in determined range of values:

Production of Metalware:

- The amount of production, $300-7105 \mathrm{t} / \mathrm{a}$.

- Capacity, 0.4-9.32 MW,

- $\mathrm{NO}_{2}$ emissions, $0.0088-9.1590 \mathrm{~kg} / \mathrm{t}$ production unit per year.

- CO emissions, 0.018 - $46.8395 \mathrm{~kg} / \mathrm{t}$ production unit per year.

- GOS emissions, $0.04-20.31 \mathrm{~kg} / \mathrm{t}$ production unit per year. Metal smelting:

- The amount of production, 3600 - 150000t/a.

- Capacity, $0.29-22.6 \mathrm{MW}$,

- $\mathrm{NO}_{2}$ emissions, $0.29-6.33 \mathrm{~kg} / \mathrm{kW}$ capacity.

- CO emissions, $0.63-36.61 \mathrm{~kg} / \mathrm{kW}$ capacity.

Metal galvanisation:

- The amount of production, 135 - 30750t/a.

- Capacity, 0,57 - 31,47 MW,

- $\mathrm{NO}_{2}$ emissions, $0.13-3.84 \mathrm{~kg} / \mathrm{kW}$ capacity.

- $\mathrm{CO}, 0.08-11.73 \mathrm{~kg} / \mathrm{kW}$ capacity.

Considering the result acquired, it can be assumed that benchmark methodology can be applied to the metal production and processing sector.

The use of benchmarks in the process of metalware manufacturing and processing allows for an objective evaluation of the emissions produced by the companies. By using the benchmarking method, it is possible to compare companies of different capacities and production amounts. Taking into account that the benchmarks have been compared to the BAT, they can be used in order to express the emissions produced by the metal production and processing sector in Latvia in comparison to the emissions of other EU member states. The introduction of cleaner production, like installing air treatment systems, choosing an optimal operating mode, 
and installing energy-efficient equipment will allow for the reduction in the emissions amount. After the introduction of principles for cleaner production, the benchmarks can be changed, thus achieving even further reduction of the emissions in the country.

\section{FIRST CONCLUSIONS AND FUTURE WORK}

1. For establishing and describing the emissions produced by the metal production and processing sector, the set benchmarks can be used.

2. In most cases, the emissions produced by the metal production and processing sector in Latvia correspond to the amounts mentioned in the BAT. At the same time, this amount can still be reduced.

3. Certain optimisation measures should be taken in the metal production and processing sector in Latvia. These measures will allow for a reduction in the amount of emissions and energy consumption.

4. There is a need for a stricter recording of the electric energy consumption and introduction of specific standards of electric energy consumption. This would ensure higher energyefficiency and reduce the total impact of manufacturing companies on the environment.

5. The specified benchmarks should be met within the next five years. After 2015 the emissions benchmarks should be reviewed.

6. Air emissions benchmarks for other production sectors of Latvia should be worked out.

\section{REFERENCE}

1. Booth, PN., Salatas, JH., Kaetzel, RS. et.al. Risk Assessment as a Decision-Making Tool for Treatment of Emissions at a New Aluminum
Smelter in Iceland: 1. Background and Introduction. Human And Ecological Risk Assessment, 2009, Nr. 17, p. 423-441.

2. Law on Pollution (Adopted 15 March 2001 by The Parliament of the Republic of Latvia).

3. Procedure by which Polluting Activities of Category A, B and C shall be Declares and Permits for the Performance of Category A and B Pollution Activities shall be Issued (Adopted 30 November 2010 by The Parliament of the Republic of Latvia).

4. Waste Management Law (Adopted 28 October 2010 by The Parliament of the Republic of Latvia)

5. Reference Document on Best Available Techniques in the Non Ferrous Metals Industries, 2001 - Integrated Pollution Prevention and Control (IPPC), European Commission.

6. Review on installations that emit volatile organic compounds (VOC) in 2005, 2006 - R.: Latvian Environment, Geology and Meteorology agency, 2006.

7. Strategic Environmental Impact Assessment for Latvian sustainability strategy 2030, 2009 - R.: Ministry of Regional Development and Local Government affairs, 2009.

8. Reference Document on Best Available Techniques in the Ferrous Metals Processing Industry, 2001 - Integrated Pollution Prevention and Control (IPPC), European Commission.

Jelena Pubule, M. Sc., Researcher

Institute of Energy Systems and Environment, Riga Technical University

Address: Kronvalda blvd. 1, Riga, LV-1010, Latvia

Phone: + 37167089088

e-mail: jelena.pubule@rtu.lv

Dace Zahare, B. Sc.

Institute of Energy Systems and Environment, Riga Technical University

Address: Kronvalda blvd. 1, Riga, LV-1010, Latvia

Phone: + 37167089088

e-mail: jelena.pubule@rtu.lv

Dagnija Blumberga, Dr.habil.sc.ing., professor

Institute of Environment and Energy Systems, Riga Technical University

Address: Kronvalda blvd. 1, Riga, LV 1010, Latvia

Phone: 371 67089923, 37167089908 ,

e-mail: dagnija.blumberga@rtu.lv

Jel̦ena Pubule, Dace Zahare, Dagnija Blumberga. Latvijas metāla ražošanas un apstrādes uzṇēmumu emisiju gaisā raksturojums

Latvijas attīstība nav iedomājama bez ražošanas sektora īpatsvara palielināšanas. Ražošanas sektora attīstība saistīta ar ražošanas jaudu kāpināšanas un no tā izrietošo seku - gaisa emisiju īpatsvara pieaugumu. Pielietojot tīrākas ražošanas principus, emisijas apjomus var ievērojami samazināt. Metāla ražošanas un apstrādes sektors Latvijā ir ieņēmis savu stabilu pozīciju tautsaimniecībā. Latvijā tiek veikta krāsaino un melno metālu kausēšana, metāla izstrādājumu ražošana, materiālu galvanizācija utt. Visu šo procesu rezultātā gaisā nonāk piesārņojošas vielas. Līdz šim nav veikta gaisa emisiju analīze atsevišķam ražošanas sektoram un nav izstrādāti metāla ražošanas un apstrādes sektora optimizācijas risinājumi. Lai varētu runāt par emisiju samazinājumu un tīrākas ražošanas ieviešanas iespējām, ir nepieciešams veikt esošās situācijas inventarizāciju. Šī raksta ietvaros tiek apskatītas Latvijas metāla ražošanas un apstrādes sektora gaisa piesārnojošo vielu emisijas, un, izmantojot līmenatzīmes metodi, noteikti optimālie emisiju apjomi sektoram. Ir izstrādātas līmenatzīmes NO${ }_{2}$, CO un GOS emisijām metāla ražošanas un apstrādes sektora sekojošiem apakšsektoriem: metālu rūpnieciskās apstrādes iekārtās; metālu kausēšanas iekārtās; iekārtās, kurās izmanto elektrolīzi vai k̦īmiskus procesus metāla virsmu apstrādei.

Елена Пубуле, Дасе Захаре, Дагния Блумберга. Характеристика выбросов загрязняющих веществ в атмосферу латвийскими металлургическими и металлообрабатывающими предприятиями.

Развитие Латвии не представляется возможным без увеличения доли производственного сектора экономики. Развитие производственного сектора напрямую связано с увеличением выбросов загрязняющих веществ в атмосферу. Применяя принципы условно чистого производства, возможно значительное снижение эмиссий загрязняющих веществ в атмосферу. Сектор металлопроизводства и металлообработки занял свою стабильную позицию в народном хозяйстве Латвии. В Латвии проводится переплавка цветных и черных металлов, развито производство и переплавка металлоизделий, гальванизация материалов и т.д. В результате этих процессов в атмосферу выбрасываются загрязняющие вещества. До сих пор в Латвии не проводился анализ выбросов загрязняющих веществ отдельных производственных секторов и не разработаны решения оптимизации. Прежде чем говорить о снижении эмиссий загрязняющих веществ и возможности внедрения чистых технологий, необходимо провести инвентаризацию имеющейся ситуации. В рамках этой статьи рассматривается эмиссия загрязняющих веществ в атмосферу латвийскими металлургическими и металлообрабатывающими предприятиями, и используя метод отметки уровня, определены оптимальные объемы эмиссии загрязняющих веществ данного сектора производства. Разработаны отметки уровня $\mathrm{NO}_{2}$, СО и ЛОС эмиссиям для существующих подсекторов металлопроизводства и металлообработки, оборудованию для промышленной металлообработки, оборудованию для металлоплавки, оборудованию для металлообработки с использованием электролиза или химических процессов для обработки металлических поверхностей. 